\title{
Mucosal Human Defensins 5 and 6 Antagonize the Anti-HIV Activity of Candidate Polyanion Microbicides
}

\author{
Jian Ding ${ }^{a} \quad$ Aprille Rapistac $^{c}$ Natalia Teleshovac Wuyuan Lu ${ }^{\mathrm{d}}$ Mary E. Klotman ${ }^{c}$ \\ Theresa L. Chang ${ }^{a, b}, c$ \\ a Public Health Research Institute and b Department of Microbiology and Molecular Genetics, University of \\ Medicine and Dentistry of New Jersey, New Jersey Medical School, Newark, N.J., 'Department of Medicine, \\ Division of Infectious Diseases, Mount Sinai School of Medicine, New York, N.Y., and IInstitute of Human Virology \\ and Department of Biochemistry and Molecular Biology, University of Maryland School of Medicine, \\ Baltimore, Md., USA
}

\section{Key Words}

Defensins $\cdot$ HIV $\cdot$ Polyanion microbicides

\begin{abstract}
Defensins are highly abundant antimicrobial peptides in the female genital mucosa. We have previously shown that human defensins 5 and 6 (HD5 and HD6), produced by cervicovaginal epithelial cells, significantly enhance HIV infectivity in vitro. Candidate polyanion microbicides, including PRO 2000, cellulose sulfate and carrageenan, failed to protect women against HIV infection in large-scale clinical trials, but the molecular basis of ineffectiveness was not clear. We hypothesized that mucosal host factors such as HD5 an HD6 may alter the activity of polyanion microbicides against HIV. Our results demonstrated that HD5 and HD6 but not their linear analogs antagonized the anti-HIV activity of PRO 2000, cellulose sulfate and carrageenan in vitro. Polyanion microbicides also reduced the HIV-enhancing effect of these defensins. We conclude that mucosal host factors could negatively impact the efficacy of topical microbicides against HIV, and their impact on the activity of candidate microbicides needs to be considered during the preclinical evaluation.
\end{abstract}

Copyright $\odot 2010$ S. Karger AG, Basel

\section{KARGER}

Fax +41613061234

E-Mail karger@karger.ch

www.karger.com
(C) 2010 S. Karger AG, Basel

Accessible online at: www.karger.com/jin

\section{Introduction}

Sulfated or sulfonated negatively charged polymers including PRO 2000, cellulose sulfate (CS) and carrageenan have been evaluated in large-scale phase III clinical trials as topical microbicides to prevent HIV transmission in women. Disappointing results from trial studies demonstrated not only that CS and carrageenan were ineffective [1-3], but that CS may have increased the risk of HIV infection [2]. In the HIV Prevention Trial Network (HPTN) 035 study ( $\mathrm{n}=3,087), 0.5 \%$ PRO 2000 gel was found to reduce the risk of HIV transmission by $30 \%$ compared with a placebo gel or no gel at all, but the effect was not statistically significant [4]. Recently, the Microbicides Development Programme (MDP) 301 trial study ( $=$ 9,385) demonstrated that PRO 2000 did not protect women against HIV infection (http://www.mdp.mrc.ac.uk/ archive.html). The molecular basis of ineffectiveness of PRO 2000, CS and carrageenan in clinical trials is not clear. While it has been suggested that low concentrations of CS and PRO 2000 could enhance HIV infection [5, 6], several studies demonstrate significant anti-HIV activities of these polyanionic polymers in vitro and ex vivo using various experimental systems [7-9]. These results

\footnotetext{
Dr. Theresa L. Chang

Public Health Research Institute, UMDNJ-New Jersey Medical School 225 Warren Street, Newark, NJ 07103 (USA)

Tel. +1 973854 3265, Fax +1 973854 3101, E-Mail changth@umdnj.edu
} 
suggest that the reasons for the ineffectiveness of these polyanionic polymers may be complex.

Mammalian defensins are antimicrobial peptides important to innate host defense [10]. Defensin levels are frequently elevated in response to infection in the mucosa [11-13], suggesting a potential role in modulating HIV transmission. Human defensins 5 and 6 (HD5 and HD6) are highly expressed in intestinal Paneth cells and are also found in the genital mucosa [14-16]. Induction of HD5 has been reported in the genital fluid from subjects infected with Chlamydia trachomatis, Neisseria gonorrhoeae infection [12] or bacterial vaginosis [13]; all are associated with an increase in the likelihood of HIV transmission [17-20]. We have demonstrated that HD5 and HD6 significantly enhance HIV entry [21]. In addition, induction of HD5 and HD6 in response to gonococcal infection increases HIV infectivity [21]. HD5 is normally present at a concentration of $1-50 \mu \mathrm{g} / \mathrm{ml}$ in the cervicovaginal larvage and can be induced 10 - to 30 -fold in response to sexually transmitted infections $[12,13,16]$.

In this study, we hypothesize that endogenous host factors such as HD5 and HD6 at the genital mucosa negatively impact the efficacy of candidate polyanion microbicides for HIV prevention. Our results demonstrate that HD5 and HD6 antagonize anti-HIV activity of polyanionic polymers in both HeLa-CD4-CCR5 cells and primary peripheral blood lymphocytes (PBLs), suggesting that it is important to consider the influence of host innate effectors on the efficacy of microbicides during preclinical evaluation.

\section{Methods}

\section{Reagents}

Recombinant human interleukin 2 (IL-2) was purchased from R\&D Systems (Minneapolis, Minn., USA). Phytohemagglutinin (PHA), iota- and $\lambda$-carrageenan were from Sigma-Aldrich (St. Louis, Mo., USA). CS was purchased from Fisher (Pittsburgh, Pa., USA). PRO 2000 was kindly provided by Albert Profy at Endo Pharmaceuticals (Chadds Ford, Pa., USA). HD5 and HD6 as well as their linear unstructured forms, [Abu]HD5 and [Abu]HD6, in which the six cysteine residues were replaced by isosteric $\alpha$-aminobutyric acid (Abu) were chemically synthesized and folded as described previously [22]. The molecular mass and structure of the peptides were verified as described previously $[22,23]$.

\section{Cell Culture}

PBLs from normal healthy blood donors were isolated by $\mathrm{Fi}$ coll-Hypaque gradient centrifugation followed by the removal of monocytes using a CD14-positive selection kit from Miltenyi Biotech (Auburn, Calif., USA). PBLs were stimulated with PHA at $5 \mu \mathrm{g} / \mathrm{ml}$ and maintained in RPMI media supplemented with $10 \%$ fetal bovine serum (FBS) and IL-2 at 25 units $/ \mathrm{ml}$ for 3 days at $37^{\circ} \mathrm{C}$ prior to viral infection. HeLa-CD4-CCR 5 cells were provided by David Kabat (University of Oregon, Portland, Oreg., USA) and maintained in Dulbecco's minimal essential medium containing $10 \%$ FBS.

\section{HIV-1 Infection}

Serum-free replication-defective HIV-1 JR-FL $_{\text {Env-pseudotyped, }}$ luciferase-expressing reporter viruses were produced as described previously [21]. HIV-1 IR-FL pseudotyped luciferase reporter virus was incubated with polyanionic polymers at varying concentrations in the presence or absence of HD5, HD6 at $37^{\circ} \mathrm{C}$ for $1 \mathrm{~h}$. Samples without polyanionic polymers were included as control. FBS at a final concentration of $10 \%(\mathrm{v} / \mathrm{v})$ was added to the mixture of virus with various treatments before exposure to HeLa-CD4CCR 5 cells $\left(5 \times 10^{4}\right.$ cells per well in a 48 -well plate $)$ or PHA-activated PBLs $\left(1 \times 10^{6}\right.$ per sample $)$ for $2 \mathrm{~h}$ at $37^{\circ} \mathrm{C}$. Unbound virus was removed by washing and infected cells were incubated at $37^{\circ} \mathrm{C}$ for $48 \mathrm{~h}$ before lysis with passive lysis buffer (Promega Inc., Madison, Wisc., USA). Luciferase activity (relative light units) reflecting viral infection was measured on an EG \& G MiniLumat LB9506 luminometer (Berthold, Bad Wildbad, Germany).

\section{Results}

Polyanion microbicides and HD5/HD6 primarily act on HIV entry. To determine whether HD5 and HD6 could affect the anti-HIV activity of candidate polyanion microbicides, $\mathrm{HIV}-1_{\text {JR-FL }}$ reporter virus was first incubated with various concentrations of PRO 2000, CS or iota-carrageenan in the presence or absence of HD5 and HD6 for $1 \mathrm{~h}$. The virus mixture was then added to HeLa-CD4CCR 5 cells for $2 \mathrm{~h}$. After washing off unbound virus, infected cells were cultured for $48 \mathrm{~h}$ before measurement of luciferase activity. HIV infection was examined as described in the Methods section. As expected, PRO 2000 $(1 \mu \mathrm{g} / \mathrm{ml})$, CS $(1 \mu \mathrm{g} / \mathrm{ml})$ and carrageenan $(10 \mu \mathrm{g} / \mathrm{ml})$ inhibited HIV infection by $90 \%$. Interestingly, PRO 2000 at $1 \mu \mathrm{g} / \mathrm{ml}, \mathrm{CS}$ at $10 \mu \mathrm{g} / \mathrm{ml}$ and carrageenan at $100 \mu \mathrm{g} / \mathrm{ml} \mathrm{lost}$ their anti-HIV activity in the presence of HD5 and HD6, although PRO 2000 at $10 \mu \mathrm{g} / \mathrm{ml}$ remained active against HIV infection (fig. 1a-c). The linear unstructured analogs of HD5 and HD6 with identical charges, [Abu]HD5 and [Abu]HD6 [22], did not promote HIV infection [21] nor did they interfere with the anti-HIV activities of PRO 2000, CS and carrageenan (fig. 1d). This result indicated that properly folded peptides were required for interference with the anti-HIV activities of polyanion microbicides.

To confirm the impact of defensins on the anti-HIV activity of these polyanionic polymers in primary HIV target cells, PHA-activated PBLs were exposed to HIV with or 
Fig. 1. Effect of candidate polyanion microbicides on HIV infection of HeLaCD4-CCR5 cells in the presence of HD5 and 6 . HIV-1 $1_{\text {JR-FL }}$ pseudotyped luciferase reporter virus was incubated with PRO 2000 (a), CS (b) and iota-carrageenan (c) in the presence (right panels) or absence (left panels) of HD5 or HD6 at $20 \mu \mathrm{g} / \mathrm{ml}$ for $1 \mathrm{~h}$ at $37^{\circ} \mathrm{C}$. The mixture of virus with various treatments was added to $\mathrm{HeLa}$ CD4-CCR5. The HIV infection assay was performed as described in the Methods section. Data are means \pm SD of triplicate samples and represent 4 independent experiments. The difference between defensin-treated samples versus untreated samples in the presence of the same concentration of inhibitors was analyzed by the two-tailed, paired Student's t test $\left({ }^{*} \mathrm{p}<\right.$ 0.05). d The effect of PRO $2000(1 \mu \mathrm{g} / \mathrm{ml})$, CS $(10 \mu \mathrm{g} / \mathrm{ml})$ and iota-carrageenan (100 $\mu \mathrm{g} / \mathrm{ml})$ on HIV infection in the presence of linear analogs of HD5 and HD6 $(20 \mu \mathrm{g} /$ $\mathrm{ml}$ ) with identical charges was determined. Samples without defensin treatment were included as a control (untreated). The untreated control for carrageenan contained DMSO (1\%) that was used as a solvent. The difference between the untreated control and samples in [Abu]HD5 or [Abu]HD6 is not significant $\left({ }^{+} \mathrm{p}>0.05\right)$. Data are means \pm SD of triplicate samples and represent 2 independent experiments. $\mathrm{RLU}=$ Relative light units.
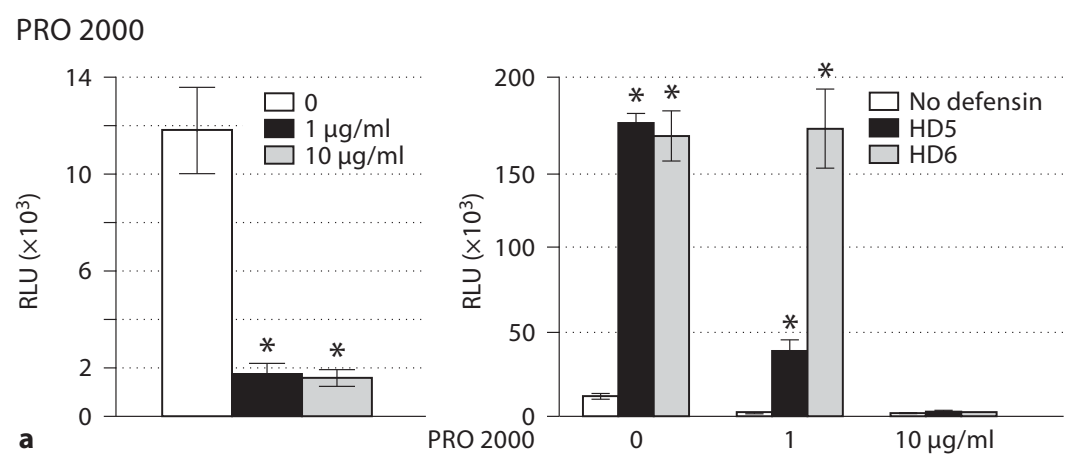

Cellulose sulfate
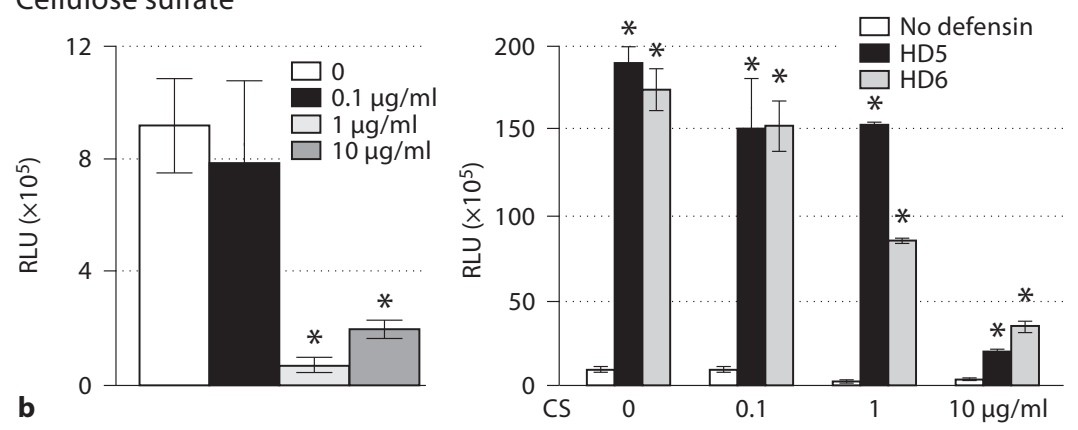

\section{Carrageenan}
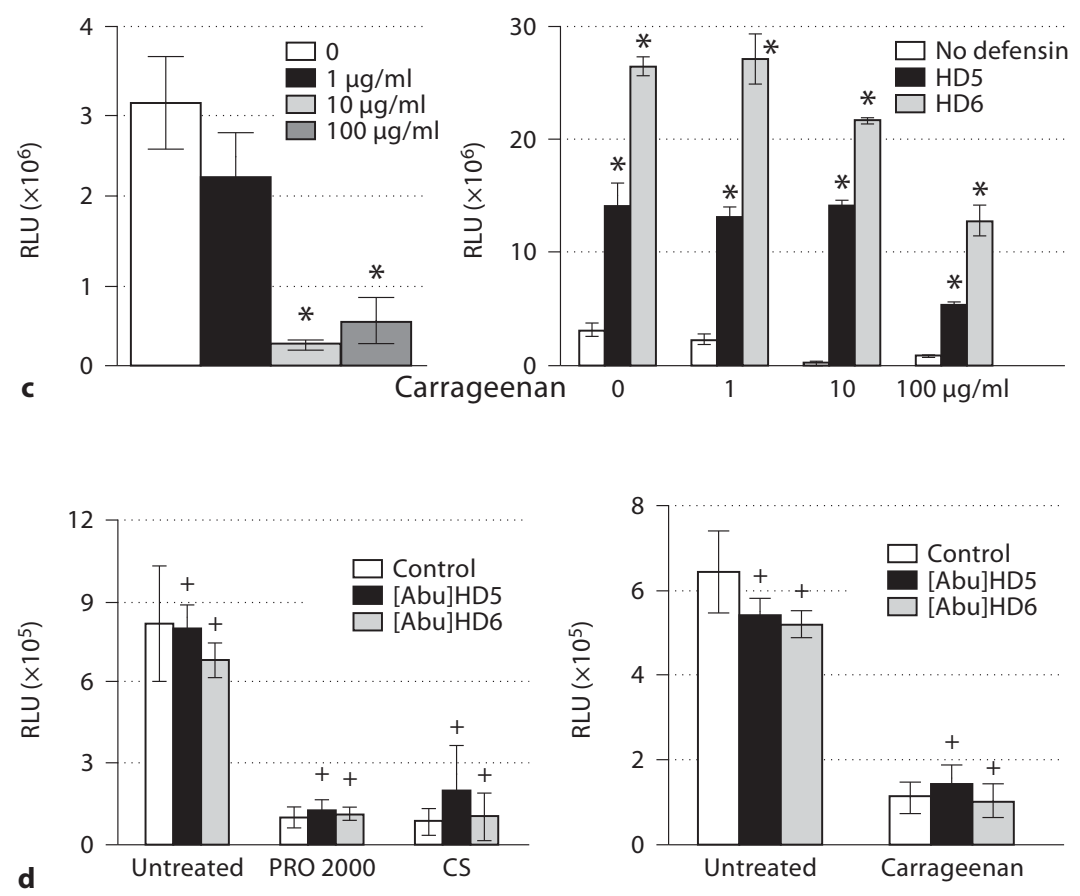
Fig. 2. HD5 and HD6 antagonized the anti-HIV activity of polyanionic polymers in PBLs. The effect of defensins on polyanionic polymers was determined using PHA-activated PBLs. HIV infection was performed as described in the method section. Data are means \pm SD of triplicate samples and represent three experiments using PBLs from different donors. ${ }^{*} \mathrm{p}<$ 0.05 , defensin-treated samples versus untreated samples in the presence of the same concentration of inhibitors. RLU = Relative light units.

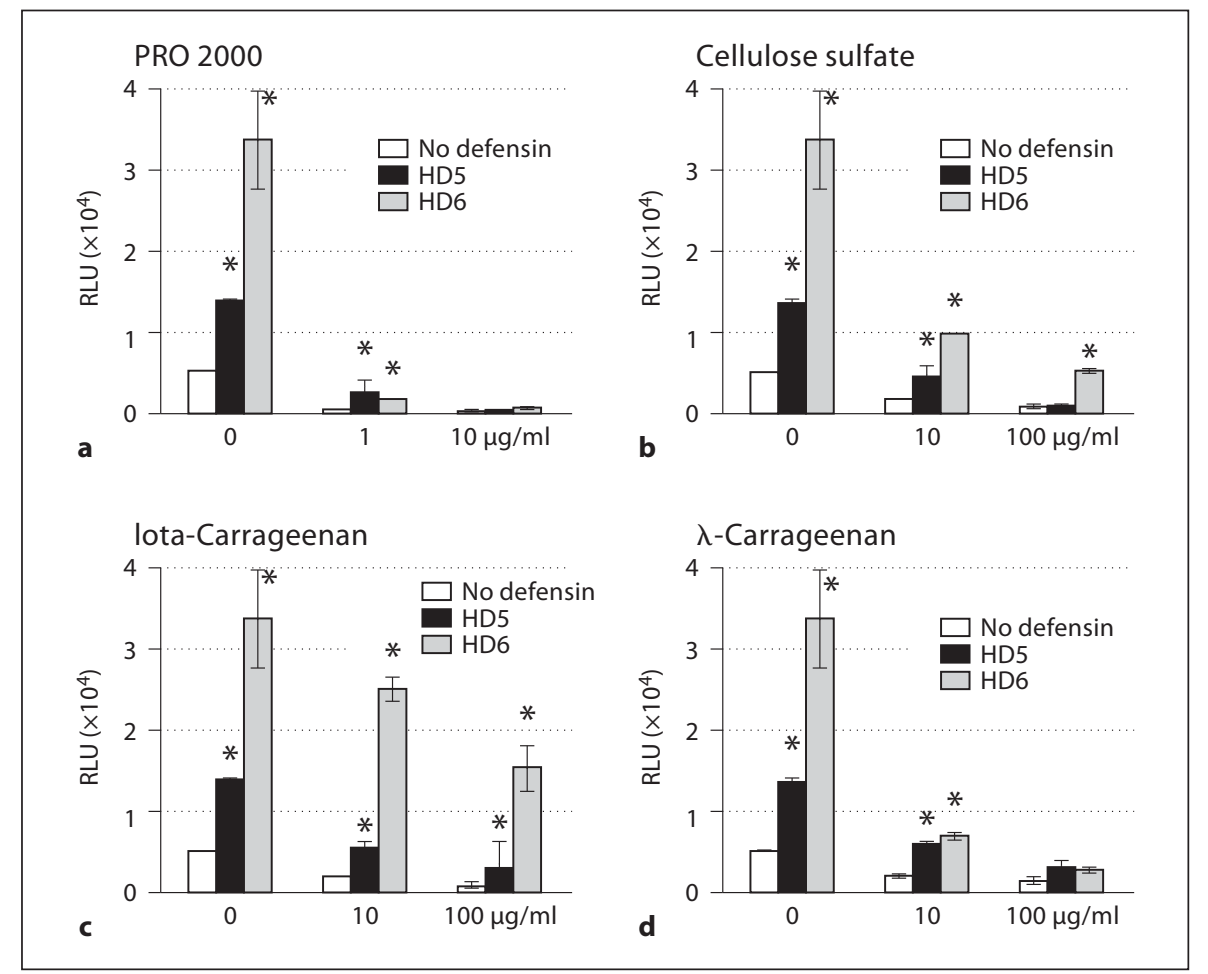

without polyanionic polymers in the presence or absence of defensins. In addition to Iota-carrageenan, $\lambda$-carrageenan was included in HIV infection of primary cells, as it was one of the active ingredients of the vaginal microbicide Carraguard. Similar to results found in HeLa-CD4-CCR5 cells, the anti-HIV activity of PRO $2000(1 \mu \mathrm{g} / \mathrm{ml})$, CS (10 and $100 \mu \mathrm{g} / \mathrm{ml}$ ), iota-carrageenan (10 and $100 \mu \mathrm{g} / \mathrm{ml}$ ) and $\lambda$-carrageenan $(10 \mu \mathrm{g} / \mathrm{ml})$ was significantly reduced or abolished in the presence of defensins (fig. 2). PRO 2000 appeared to be a more effective inhibitor in the presence of defensins compared to CS and carrageenan, as PRO 2000 at $10 \mu \mathrm{g} / \mathrm{ml}$ blocked HIV infection of PBLs in the presence of defensins. Interestingly, the degree of the HIV-enhancing effect of defensins was reduced in the presence of high concentrations of PRO 2000, CS and carrageenan.

\section{Discussion}

Our results demonstrated that the host-innate effectors HD5 and HD6 antagonized the anti-HIV activity of polyanionic polymers in both HeLa-CD4-CCR5 cell lines and primary PBLs. Induction of HD5 has been reported in genital fluid from individuals with $C$. trachomatis and $N$. gonorrhoeae infection and with bacterial vaginosis [12,
13]. We have demonstrated that HD5 and HD6 significantly enhance HIV infectivity and that induction of these defensins contributes to enhanced HIV infection of conditioned media from $N$. gonorrhoeae-exposed vaginal epithelial cells [21]. Our recent preliminary data using different collection methods of clinical specimens revealed that HD5 was highly abundant in the endocervix from women without sexually transmitted infections. The levels of HD5 in endocervical samples collected by Merocel ophthalmic sponges (eluted in $0.7 \mathrm{ml} ; \mathrm{n}=12$ ) and cytobrushes (in $3.5 \mathrm{ml} ; \mathrm{n}=10$ ) were approximately 400 and 58 $\mu \mathrm{g} / \mathrm{ml}$, respectively (unpubl. data). Therefore, the defensin concentrations used in this study were clinically relevant and the amount of HD5 in the endocervix was sufficient to antagonize polyanion microbicides.

While HD5 and HD6 interfered with the anti-HIV activity of polyanion microbicides, these polyanionic polymers also reduced HIV enhancing of HD5 and HD6. Both PRO 2000 and HD5/HD6 act on the step of HIV entry [8, 21]. It remains to be determined whether there is a competition between defensins and polyanionic polymers for HIV glycoproteins or whether it is simply the sum of the independent defensin and microbicide activities.

Reduction of anti-HIV activity of polyanionic polymers including polymethylenehydroquinone sulfonate 
and CS in diluted cervicovaginal lavage has been documented [8]. In addition to HD5 and HD6, other HIVenhancing peptides have been reported in human semen (semen-derived enhancer of viral infection) [24]. The HIV-enhancing effect of semen-derived enhancer of viral infection was abolished by polyanionic compounds [25], while the HD5 and HD6 enhancing effect was relatively resistant to most polyanionic polymers, except PRO 2000, indicating that these peptides may promote HIV infection through specific mechanisms. While it remains to be determined whether HD5 and HD6 contribute to reduced efficacy of polyanion microbicides in the presence of cervicovaginal specimens, our results highlight the potential negative effect of mucosal host factors that needs to be considered during pre-clinical evaluation of microbicides to prevent HIV spread.

\section{Acknowledgements}

We thank Issar Smith and Albert Profy for critical reading of the manuscript and insightful comments. This work was supported by NIH grants AI073205 and AI081159 (to T.L.C.) and AI061482 (to W.L.).

\section{References}

1 Skoler-Karpoff S, Ramjee G, Ahmed K, Altini L, Plagianos MG, Friedland B, Govender S, De Kock A, Cassim N, Palanee T, Dozier G, Maguire R, Lahteenmaki P: Efficacy of Carraguard for prevention of HIV infection in women in South Africa: a randomised, double-blind, placebo-controlled trial. Lancet 2008;372:1977-1987.

-2 Van Damme L, Govinden R, Mirembe FM, Guedou F, Solomon S, Becker ML, Pradeep BS, Krishnan AK, Alary M, Pande B, Ramjee G, Deese J, Crucitti T, Taylor D: Lack of effectiveness of cellulose sulfate gel for the prevention of vaginal HIV transmission. N Engl J Med 2008;359:463-472.

3 Halpern V, Ogunsola F, Obunge O, Wang $\mathrm{CH}$, Onyejepu N, Oduyebo O, Taylor D, McNeil L, Mehta N, Umo-Otong J, Otusanya S, Crucitti T, Abdellati S: Effectiveness of cellulose sulfate vaginal gel for the prevention of HIV infection: results of a phase III trial in Nigeria. PLoS ONE 2008;3:e3784.

4 Karim SA, Coletti A, Richardson B, Ramjee G, Hoffman I, Chirenje M, Taha T, Kapina M, Maslankowski L, Soto-Torres L: Safety and effectiveness of vaginal microbicides BufferGel and 0.5\% PRO 2000/5 Gel for the prevention of HIV infection in women: results of the HPTN 035 trial. CROI 2009 2009:Abstract 48LB.

5 Rusconi S, Moonis M, Merrill DP, Pallai PV, Neidhardt EA, Singh SK, Willis KJ, Osburne MS, Profy AT, Jenson JC, Hirsch MS: Naphthalene sulfonate polymers with CD4-blocking and anti-human immunodeficiency virus type 1 activities. Antimicrob Agents Chemother 1996;40:234-236.

6 Tao W, Richards C, Hamer D: Enhancement of HIV infection by cellulose sulfate. AIDS Res Hum Retroviruses 2008;24:925-929.

7 Pearce-Pratt R, Phillips DM: Sulfated polysaccharides inhibit lymphocyte-to-epithelial transmission of human immunodeficiency virus-1. Biol Reprod 1996;54:173-182.

${ }_{8}$ Scordi-Bello IA, Mosoian A, He C, Chen Y, Cheng Y, Jarvis GA, Keller MJ, Hogarty K, Waller DP, Profy AT, Herold BC, Klotman ME: Candidate sulfonated and sulfated topical microbicides: comparison of anti-human immunodeficiency virus activities and mechanisms of action. Antimicrob Agents Chemother 2005;49:3607-3615.

-9 Fletcher PS, Wallace GS, Mesquita PM, Shattock RJ: Candidate polyanion microbicides inhibit HIV-1 infection and dissemination pathways in human cervical explants. Retrovirology 2006;3:46.

10 Ganz T: Defensins: antimicrobial peptides of innate immunity. Nat Rev Immunol 2003;3: 710-720.

-11 Levinson P, Kaul R, Kimani J, Ngugi E, Moses S, Macdonald KS, Broliden K, Hirbod T: Levels of innate immune factors in genital fluids: association of $\alpha$ defensins and LL-37 with genital infections and increased HIV acquisition. Aids 2009;23:309-317.

-12 Porter E, Yang H, Yavagal S, Preza GC, Murillo O, Lima H, Greene S, Mahoozi L, KleinPatel M, Diamond G, Gulati S, Ganz T, Rice PA, Quayle AJ: Distinct defensin profiles in Neisseria gonorrhoeae and Chlamydia trachomatis urethritis reveal novel epithelial cell-neutrophil interactions. Infect Immun 2005;73:4823-4833.

13 Fan SR, Liu XP, Liao QP: Human defensins and cytokines in vaginal lavage fluid of women with bacterial vaginosis. Int J Gynaecol Obstet 2008.

14 Jones DE, Bevins CL: Defensin-6 mRNA in human Paneth cells: implications for antimicrobial peptides in host defense of the human bowel. FEBS Lett 1993;315:187-192.

15 Jones DE, Bevins CL: Paneth cells of the human small intestine express an antimicrobial peptide gene. J Biol Chem 1992;267: 23216-23225.

16 Quayle AJ, Porter EM, Nussbaum AA, Wang YM, Brabec C, Yip KP, Mok SC: Gene expression, immunolocalization, and secretion of human defensin-5 in human female reproductive tract. Am J Pathol 1998;152:12471258.

17 Fleming DT, Wasserheit JN: From epidemiological synergy to public health policy and practice: the contribution of other sexually transmitted diseases to sexual transmission of HIV infection. Sex Transm Infect 1999;75: 3-17.

18 Galvin SR, Cohen MS: The role of sexually transmitted diseases in HIV transmission. Nat Rev Microbiol 2004;2:33-42.

19 Plummer FA: Heterosexual transmission of human immunodeficiency virus type 1 (HIV): interactions of conventional sexually transmitted diseases, hormonal contraception and HIV-1. AIDS Res Hum Retroviruses 1998;14 Suppl 1:S5-S10.

20 Cohen MS, Hoffman IF, Royce RA, Kazembe P, Dyer JR, Daly CC, Zimba D, Vernazza PL, Maida M, Fiscus SA, Eron JJ Jr: Reduction of concentration of HIV-1 in semen after treatment of urethritis: implications for prevention of sexual transmission of HIV-1. AIDSCAP Malawi Research Group. Lancet 1997; 349:1868-1873.

21 Klotman ME, Rapista A, Teleshova N, Micsenyi A, Jarvis GA, Lu W, Porter E, Chang TL: Neisseria gonorrhoeae-induced human defensins 5 and 6 increase HIV infectivity: role in enhanced transmission. J Immunol 2008;180:6176-6185.

22 Wu Z, Ericksen B, Tucker K, Lubkowski J, Lu W: Synthesis and characterization of human $\alpha$-defensins 4-6. J Pept Res 2004;64:118-125.

-23 Szyk A, Wu Z, Tucker K, Yang D, Lu W, Lubkowski J: Crystal structures of human $\alpha$-defensins HNP4, HD5, and HD6. Protein Sci 2006;15:2749-2760.

24 Munch J, Rucker E, Standker L, Adermann $\mathrm{K}$, Goffinet C, Schindler M, Wildum S, Chinnadurai R, Rajan D, Specht A, Gimenez-Gallego G, Sanchez PC, Fowler DM, Koulov A, Kelly JW, Mothes W, Grivel JC, Margolis L, Keppler OT, Forssmann WG, Kirchhoff F: Semen-derived amyloid fibrils drastically enhance HIV infection. Cell 2007;131:1059-1071.

25 Roan NR, Münch J, Arhel N, Mothes W, Neidleman J, Kobayashi A, Smith-McCune K, Kirchhoff F, Greene WC: The cationic properties of SEVI underlie its ability to enhance HIV infection. J Virol 2009;83:73-80. 